\title{
The Management of Community Education in Rural Areas by Religious Educational Institutions
}

\author{
Mohamad Mustari \\ (Ministry of Education and Culture of the Republic of Indonesia; \\ mohamad.mustari@,kemdikbud.go.id)
}

\begin{abstract}
Abstrak
Artikel ini membahas bagaimana lembaga pendidikan publik seperti pesantren menghadapi perubahan sosial yang disebabkan oleb modernitas. Asumsinya adalab bahwa sebagai agen perubahan, tentu saja pesantren harus mengikuti apa dan bagaimana modernitas itu sendiri sebelum bisa memberikan jawaban kepada masyarakat. Yang terutama dibawa oleh modernitas itu sendiri adalah pembangunan. Karena itu, perubahan sosial yang harus dijawab terutama oleh pesantren adalah masalah perkembangan. Studi ini menemukan bahwa secara operasional, bubungan antara pesantren dan pengembangan masyarakat pedesaan, yang bercita-cita untuk meningkatkan kualitas sumber daya manusia di pesantren, telah dilakukan melalui kegiatan berikut: konsolidasi dan kerja sama, bubungan bisnis dan pendidikan, dan wawasan ke dalam perjuangan pesantren, masyarakat, dan pemerintah.
\end{abstract}

\section{Kata kunci: Pendidikan Masyarakat, Jejaring Sosial, Perubahan Sosial, Program Pembangunan}

\begin{abstract}
This article discusses how public education institutions such as boarding schools face the social changes brought about by modernity. The assumption is that as agents of change, of course pesantren must follow what and how modernity itself before providing answers to society. What is mainly brought about by modernity itself is development. Therefore, social change that must be answered primarily by pesantren is a matter of development. This study found that operationally, the relationship between pesantren and rural community development, which aspires to improve the quality of human resources in the pesantren, has been carried out through the following activities: consolidation and cooperation, business links and education, and insights into the pesantren's struggle, community, and the government.
\end{abstract}

Keywords: Community Education, Social Networking, Social Change, Development Programs 


\section{A. INTRODUCTION}

The decade of the sixties has declared the first decade of world development, the decade of the seventies as the second decade of growth, and the decade of the eighties as the third decade of development. Such a statement departs from the fact that in a world now approaching the end of the twentieth century, there are very many problems, both in one country and in the relationship between nations in various aspects of life such as in politics, economics, technology, and security. These problems can only be solved by the implementation of comprehensive development activities, in the sense of covering all aspects of national and state life (Naude, 2013: 1).

In order to advance the pesantren and improve the welfare of the people, it requires togetherness and integration between the pesantren community. Therefore, consolidation needs to be realized so that ukhuwah Islamiyah, togetherness and integration are maintained. The combination and union of pesantren with the community is the basic capital for the successful development of Islamic boarding schools. The togetherness and integration of pesantren with the community is the basic capital towards the development of the pesantren itself. In essence, these two elements try to overcome the problems faced in addition to building their environmental areas, namely between pesantren and the community to support and complement each other (Mustari \& Rahman, 2010).

To accelerate the development of Islamic boarding schools both from the aspects of education, management and the economy, cooperation with external parties, both the government and the private sector needs to be realized. The 
cooperative relationship with outside parties will provide access to capital, technology, management and education to Islamic boarding schools in accelerating the process of advancing Islamic boarding schools both economically, education and management. This condition has a large impact on the environment of the local community, namely the place where the pesantren is located, both in terms of improving the quality of life and from an economic perspective (Malik, 2005).

The existence of pesantren greatly influences society. This is because the pesantren leaders are religious leaders and local community leaders who become role models and examples for the community. Islamic boarding schools are also the basis for driving development and overcoming problems that apply in society.

\section{B. LITERATURE REVIEW}

It has been recognized that pesantren have an important role as agents of social renewal, especially in transmigration programs, socialization of family planning systems, environmental awareness movements or movements of santri and local communities in the improvement of physical facilities and development of village communities, organizing polyclinics for surrounding community members and so on. Of all these elements, the most prominent is the ability of pesantren to provide educational facilities that are relatively cheap and can be paid by the community (Rahardjo, 1985).

Thus, behind its simplicity and traditionality, pesantren have emancipation values that are able to develop self-sufficient education. This kind of indigenous socio-cultural wealth must be recognized as a positive effort in order to spur 
modernization in society in the midst of an underdeveloped nation. In turn, this will eliminate dependency on developed countries.

Developing countries are often faced with a choice dilemma between growth and equity, between the development of the middle class in the city and the development of the rural sector, between the development of material with nonmaterial, or between development that focuses on the economy and non-economic fields (Sørensen, 2016).

Schumacher (2011) states that the main problem facing developing countries lies in two million villages that are poor and lagging. According to him, "as long as the burden of living in rural areas cannot be alleviated, the problem of poverty in this world will not be resolved and inevitably this situation will be worse." He explained: "I am convinced that from various causes of poverty, material factors such as lacking in natural wealth or without capital, insufficient infrastructure is only the second reason. The main causes are deficiencies in the fields of education, organization, and discipline."

The importance of rural development in nation-building is indeed based on the idea that rural communities are a social system which can be described as relatively undeveloped, bound to local norms that are traditional and static. Changes that occur in general run very slowly. Change initiatives often come from parties outside the village. In addition, village communities are described as a whole social system, formed by various elements or subsystems (McMichael, 2012). 
Many opinions about the limitations of traditional and modern society. Soedjatmoko (2001) for example comparing human and community characteristics from the two continuum as follows:

Tabel 1. A Comparison between Traditional and Modern Society

\begin{tabular}{|c|c|c|}
\hline No. & Masyarakat Tradisional & Masyarakat Modern \\
\hline 1. & Tied to the place of origin & Mobility \\
\hline 2. & Status orientation & Orientation of achievement results \\
\hline 3. & Personal relationship & $\begin{array}{l}\text { Non-personal relations, for reasons of } \\
\text { matter }\end{array}$ \\
\hline 4. & $\begin{array}{l}\text { Primordial loyalty (religion, class, } \\
\text { ethnicity, family) }\end{array}$ & $\begin{array}{l}\text { Overarching loyalty, such as state, } \\
\text { position, profession. }\end{array}$ \\
\hline 5. & $\begin{array}{l}\text { Family organization, ties are } \\
\text { personal }\end{array}$ & $\begin{array}{l}\text { Non-personal organization, interest } \\
\text { bond or goal oriented }\end{array}$ \\
\hline 6. & Small organization (fracture) & Large organization (efficiency) \\
\hline 7. & Past orientation & Orientation for the future \\
\hline 8. & Dependant on fate & $\begin{array}{l}\text { Human problems can be overcome } \\
\text { by humans }\end{array}$ \\
\hline 9. & Relationship with nature: adjustment & $\begin{array}{l}\text { Relations with nature: mastering, at } \\
\text { least regulating }\end{array}$ \\
\hline 10. & Power relations: hierarchy & Power relations: co-archis \\
\hline 11. & Expressive culture & Progressive culture \\
\hline
\end{tabular}
Source: Soedjatmoko, 2001.

Soedjatmoko's view of the comparison of the characteristics of traditional societies with modern society is almost the same as Riggs (1973). The difference is Riggs adds the stage of a transitional society that has dualistic characteristics, a combination of the two characteristics of the continuum. This is what is called the model of prismatic society. In prismatic society, various functions are centered in one direction, gradually leading to specialization. Prismatic society is a form of transition 
from agrarian society to industrial society which has the characteristic of heterogeneity and the existence of formalism (Riggs, 2006). In terms of analyzing changes in agrarian society to industrial society, Riggs also used a structural functional approach.

According to Van den Berghe (in Lauer, 1982), structural functional theory has 7 (seven) general characteristics of perspectives which can be explained as follows:

1. Society must be analyzed as a whole, as a system consisting of interconnected parts

2. The causal relationship is "plural and interrelated"

3. The social system is always in a state of "dynamic equilibrium." Adjustments to the forces that afflict the system give rise to minimal changes in the system;

4. Perfect integration never existed. Each system experiences tensions and deviations but tends to be neutralized through institutionalization;

5. Change basically takes place slowly, which is more a process of adjustment than revolutionary change;

6. Change is the result of adjustments to changes that occur outside the system, growth through differences and through internal discoveries;

7. Communities are integrated through shared values.

To understand social change, Parsons (2013) developed a framework for the AG-I-L model, of the four functional requirements that must be met by the social system, namely: 
1. A-Adaptation; show the necessity for the social system to deal with the environment. This adaptation covers two dimensions of the problem. First, there must be an adjustment of the system to the "state of action", namely a demand for a firm and unchangeable reality that comes from the environment. Second, there is an active transformation of the situation as "a way to obtain tools for achieving goals".

2. G-Goal Attainment, is a functional requirement that is based on the view that each action is directed at certain goals. In the system, the priority is a shared goal rather than an individual's personal goal.

3. I - Integration; is a prerequisite relating to the relationship between members in the social system so that the system functions effectively as a whole. In this case solidarity is needed between individual members of a group. Solidarity and willingness to sacrifice each other is an emotional bond that becomes a binder for the integrity of the social system.

4. L- Latent Pattern Maintenance; the maintenance of patterns that remain is a concept that shows the existence of clumsiness and interaction between members of the social system, which may be caused by boredom or pressure. Therefore, other patterns of interaction must be developed that allow to restore motivational encouragement and strengthen the unification of values that are held in a social system (Poloma, 1979; Parsons, 2013).

The development of rural communities as a process of social change is basically an attempt to modernize the generally traditional village communities. The process of social change can be described through the following A-G-I-L: 
$\begin{array}{ll}\text { Villagers } & \text { Villagers }\end{array}$

\begin{tabular}{|c|c|c|c|c|}
\hline $\mathrm{A}$ & $\mathrm{G}$ & $\mathrm{A}$ & $\mathrm{G}$ \\
\hline $\mathrm{L}$ & $\mathrm{I}$ & \multirow{2}{*}{ Modernization } & $\mathrm{L}$ & $\mathrm{I}$ \\
& & & & \\
\hline
\end{tabular}

Diagram 1. Modernization of Village Communities Following Model A-G-I-L Source: Modification of Model A-G-I-L from Parsons (2013).

The direction of evolutionary social change will be determined by the process of structural differences and developments related to it. Parsons (2013) shows several specific developments that are interconnected, namely:

1. the existence of a social stratification system as a dimension of social structure that is separate and different from kinship organizations;

2. cultural legitimacy of existing political structures;

3. bureaucratic organization;

4. money system and market network;

5. universal norm framework;

6. patterns of democratic associations.

The process of function differences is closely related to achieving goals. The main institution responsible for achieving goals is the political system. Complex political systems - in the process of difference are used for purpose - carry out adaptive imperative integration in two stages called adaptive orientation. This adaptive orientation can be explained using the following A-G-I-L model: 


\begin{tabular}{|c|c|}
\hline Means: & Specific Goals: \\
Regulation & Authority \\
\hline Values: & Main norms: \\
Organizational Effectiveness & Leadership \\
\hline L & I \\
\hline
\end{tabular}

Diagram 2. High Level Generality in Political Systems

Source: Processed from Parsons (2013).

Each function category on a social system is arranged at the highest level through a value system, which is then translated into more specialized languages at the appropriate level. These norms are more limited and less general in nature compared to the value system. In other words, these norms are operational in nature so that they are the guidelines in researches.

\section{METHOD}

This research uses a qualitative approach. It is because this research explores and defines what for some people as a social or humanitarian problem (Cresswell, 2010: 146), resulting in descriptive data of observable words or behaviors (Bogdan and Taylor in Moleong, 2012: 4). While the method used in this research is a descriptive method, which is to represent the symptoms of the problems studied. As a result, this is an observation and natural atmosphere (natural setting) (Rakhmat, 2012: 24). The method is particularly suitable for researching rural development issues, as this is natural, profound, and complex (Der Wagen, 2001: 5).

The field of research is the sociology of education, namely "analysis of sociological processes involved in educational institutions" (Ball, 2013). This research 
limits itself only to aspects related to the pattern developed by pesantren in carrying out participatory actions in the development of rural communities. Thus what is mainly studied is the role of the pesantren institution itself in village development. This of course involves a variety of functional structure problems and functional analysis in relation to the overall social system and micro-community of schools (McKenzie, 2014). Therefore, this study will inevitably reveal more about the educational model he developed and also the involvement of kyai in the dualism of traditionalism and modernism (Pohl, 2006).

This research investigates social development which is a welfare program or assistance for the poor through meeting basic needs, which includes not only the opportunity to earn income, but also access to public services, such as education, health, housing, transportation, clean water, etc. (Korten and Alfonso, 1981). Thus, the conception of development here is the conception of "integrative development" (Suradisastra, 2011).

The data collection conducted in this study can be explained as follows:

1. For a comprehensive study of Islamic boarding schools that are used as cases, in-depth interviews and observations are used.

2. As for obtaining environmental data, especially physical ones, secondary data is collected, especially from district, provincial and central government institutions.

So, this study uses two categories of instruments, namely interview and observation instruments. This directly ensures the reliability of the data and findings of the study in triangulation. 
Population is defined as a collection of potential participants whose results will be used as generalizations or all collections to be reviewed (Lewis, 2015). The population of this study is Islamic boarding schools in Tasikmalaya Regency, West Java, which number around 761 Islamic boarding schools, scattered in almost all villages, or in each sub-district (mukim) in this Regency. From this population, the sample used was six Islamic boarding schools which were considered representative in accordance with the research topic. In this case the pesantren in Kab. Tasikmalaya is divided into three types of boarding schools, namely Modern, Traditional, and Combined pesantren (a mixture of Modern and Traditional types).

\section{FINDINGS AND DISCUSSION}

\section{Development in Islamic boarding schools}

In conjunction with Islamic boarding schools, the Indonesian government has two ministries that deal with the issue of primary and secondary education, namely the Ministry of National Education (Kemdiknas) which implements elementary school (SD), junior high school (SMP), high school (SMA) and high school Vocational (SMK). Meanwhile, the Ministry of Religion (Kemenag) manages Madrasah Ibtidaiyah (MI) programs, Madrasah Tsanawiyah (MTs), Madrasah Aliyah (MA), and pesantren. While the Ministry of National Education has a general curriculum, namely for all Indonesian citizens, the Ministry of Religion runs a curriculum according to the Islamic approach (Hidayat \& Machali, 2012). 
With regard to the school and madrasah system, the response of pesantren is indeed different. In Tasikmalaya Regency, there are pesantren that take the path of the two systems such as Suryalaya, Ar-Riyadh, and Persis Rajapolah. Others only take the madrasa system like Al-Furqon Islamic Boarding School. In addition, there were also those who did not take the two systems at all, as was done by the Miftahul Huda Manonjaya Islamic Boarding School and the Asy-Syahidiyah Cisayong Islamic Boarding School. The following is the result of an interview with a North Tasik Secondary Education Supervisor.

Islamic boarding schools in which there is formal or junior high school education basically have to refer to the curriculum in the curriculum of the National Education Department, and the contents of the pesantren are only added. So, the National Education Ministry's standard of content must be applied one hundred percent, only the Islamic curriculum. So on average the pesantren have a school, formal education is usually until late afternoon. That's the difference with ordinary school. That is also the same principle as Islamic boarding schools that take the Ministry of Religion curriculum. There are also Islamic boarding schools that use the Vocational School curriculum which teaches life skills. In SMA Persis Rajapolah there are plans to teach life skills that are in accordance with the environment, for example, to develop livestock and fisheries because they have good natural resources. (Interview with CS, Tasikmalaya, October 18, 2016 in Indonesian).

The reason stated by the pesantren that did not take the two systems was that the continuation of the tradition of pesantren from the previous kiai would be disrupted. This was conveyed by the leader of the Asy-Syahidiyah Islamic Boarding School. Also for the Miftahul Huda Islamic Boarding School, it was said that the pesantren was only for religious studies, and not for obtaining a diploma (Interview with Kiai AR \& AT, October 18, 2016).

The next development is the Ministry of National Education and Ministry of Religion to help the modernization process of Islamic boarding schools. Ministry of 
National Education and Ministry of Religion offer Islamic boarding schools their madrasah and school systems to be used as benchmarks for education. The school and madrasah also issued diplomas that could be used by graduates to find work. The following is an excerpt of an interview with the School Supervisor.

Actually the pesantren has good capital in terms of moral improvement. It remains that the pesantren must follow the times, namely that educational institutions can issue diplomas that can be used in formal employment. Because formal legality has been demanded by various jobs. That is why the government provides an opportunity for pesantren to open schools or madrasas. Even for those who have not opened a school or madrasa, the government offers packages $\mathrm{A}, \mathrm{B}, \mathrm{C}$ that equalize the school or madrasa. (Interview with CS, Tasikmalaya, October 18, 2016 in Indonesian).

To get the diploma, the pesantren inevitably must receive 100 percent of all curriculums that are standardized. For Islamic boarding schools that have schools or madrassas, the subjects that are Islamic in nature are only delivered when outside school hours.

For the success of education, the Ministry of National Education and Ministry of Religion help provide educational facilities such as books, laboratories and buildings. The government assistance is indeed needed by the pesantren that run schools or madrasas. But there are Islamic boarding schools that do not want to accept such assistance for certain reasons.

In addition to the official school system as above, the Indonesian government also has a Learning Group (Kejar) program, which is equalizing learning for those who are unable to learn. This pursuit has a package, which is Package A for 
equalization at the SD level; Package B for equalization in junior high school ranking; and Package $\mathrm{C}$ for equalization in high school ranking.

In summary, only traditional boarding schools have not received the basic education of the Indonesian Government. Meanwhile, a diploma recognized by the government and the community is very necessary as a provision for life after graduating from a pesantren. To handle this, the pesantren allows students to take the exam at the Chase Package and then get a diploma if they have graduated. This truth is given not to study at the Chase Package but only to take the exam. This is because religious learning in Islamic boarding schools will be disrupted if santri take part in the Kejar Paket.

\section{Village Community Development}

Actually it is not easy to provide the right definition to explain the development of rural communities. There is an assumption that the development of rural communities as a local improvement effort can be achieved based on the wishes of the community (Rahman, 2014). Therefore, certain village communities have superior ideals related to implementing their own community development. These dreams can be considered explicitly or implicitly in their philosophy of life.

However, the development of rural communities, in principle, is a movement in various forms of activities. For example in the health sector, agriculture, industry, etc., which aims to influence the increase in the life stage of the village community. The policy of the system of implementing rural community development is to spur the ability of the community itself which leads to a better standard of living. This can 
be seen in the pattern of development of village communities developed by the Government of Indonesia. For example, during the leadership of President Soeharto, there were several activities in its operations. These include various counseling such as PPL (Field Extension Officers) in the field of agriculture / livestock, environmental health / KB (Family Planning), BIMAS (Community Guidance) for BUUD / KUD (Village Unit Business Units / Village Unit Cooperatives), livestock and programs Disadvantaged Presidential Instruction (IDT) (Maskun, 1993). During President Susilo Bambang Yudhoyono's leadership, there were several activity units such as BLT (Direct Cash Assistance), BOS (School Operational Assistance), PNPM (Mandiri National Youth Program); In the days of Joko Widodo such as Healthy Indonesia, Smart Indonesia, and so on (Jamal, 2017).

The most important thing from the system of implementing the village community development is that this system is not monopolized by the government. Non-government institutions such as non-governmental organizations (NGOs) or from abroad can take part in implementing the development of this village community. This statement certainly has permission from the government (Marzali, 2016).

On the government side, besides the two ministries that have been mentioned, there are several ministries that care about pesantren. Among them are the Ministry of Cooperatives and Small and Medium Enterprises (UKM). This ministry encourages the establishment of cooperatives in Islamic boarding schools (Kopontren). Here, the ministry trains santri to become proficient personnel in the field of cooperatives. In the end the santri took care of the cooperative in their 
respective pesantren. We can see the actions of the Ministry of Cooperatives in Suryalaya Islamic Boarding School, which has also received assistance in the form of workshops. There is also a Flats program for boarding schools And many other programs. But not all pesantren receive assistance, because government funds are limited.

From the Ministry of Agriculture there are also programs involving pesantren. Among them include the provision of assistance in the form of capital such as livestock, fisheries, and superior seeds. In addition, the ministry was also asked to provide information on how to farm and raise good livestock, maintain agriculture and livestock from pests and diseases, and so on. From this program, the Suryalaya Islamic Boarding School received superior sheep seeds, which have not been obtained by other pesantren. (Interview with HBZ, October 20, 2016). Meanwhile, the Miftahul Huda Islamic Boarding School often receives lecture visits from the agricultural instructors for their santri (Interview with Kiai AT, October 18, 2016).

However, the development goals of the Indonesian government are highly expected by each pesantren while not reducing the freedom of the pesantren, whether political or otherwise. Because, there are among the pesantren in Tasikmalaya that are reluctant to be considered as the 'mouthpiece' of the government.

Actually the construction of Islamic boarding schools is parallel with regional development, which is under the national development program. Therefore, pesantren are used as agents of development by the government, while the 
development of village communities is by the pesantren and the local government. Islamic boarding schools are also open to regional development. Therefore, pesantren have been able to absorb programs both from the central government and from the regional government.

\section{Islamic Boarding School Network}

In response to the development programs launched by the government, Islamic boarding schools have established partnerships with other institutions, namely by creating cooperation with government and private institutions. Among the government institutions that have collaborated with Islamic boarding schools are the Ministry of Agriculture, a ministry that deals with agriculture, livestock, fisheries and so on. Practically, the Ministry has a Regional Level Implementation Unit (UPTD). For pesantren, the office is known as the District UPTD. Here programs such as food security are carried out jointly by the Horticultural UPTD in Tasikmalaya Regency with the Miftahul Huda Islamic Boarding School and superior sheep programs for livestock as did the UPTD in the Agriculture of Tasikmalaya District with the Suryalaya Islamic Boarding School (Interview with HBZ and Kiai AT, 20 and 18 October 2016).

Meanwhile, with the Ministry of Cooperatives and Small and Medium Enterprises (UKM), there have been Islamic boarding schools that have cooperated. For example, with the help of the ministry, Islamic boarding schools established KOPPONTREN (Koperasi Pondok Pesantren). From there the pesantren carry out various activities for the pesantren and the surrounding community. Therefore, there 
are Islamic boarding schools that receive facility assistance. Among them included the Suryalaya Islamic Boarding School which received assistance in the form of workshops and equipment.

The Ministry of Commerce has also been heavily involved with the development of Islamic boarding schools and village communities. Among the sectors supported by the Ministry are handicraft businesses which are not only sold domestically, but also sold abroad, to America and Europe. Among the pesantren that have managed the activity are the Pesantren Persis Rajapolah (Interview with AMP, October 20, 2016).

In terms of finance, Islamic boarding schools are not only related to the Ministry of Cooperatives but also to the banking sector (especially Islamic banking). As a result the pesantren established the BMT (Baitul Mal wa Tamwil).

Collaborated cooperation is not based on parties within the country, but cooperation with foreign parties is also held for the sake of the progress of the pesantren and the community. Among those outside the country involved in the development of Islamic boarding schools and Muslim communities are Gulf countries such as Saudi Arabia, Kuwait, Qatar and Bahrain. Pesantren Persis Rajapolah, for example, received donations from the Mu'assasah Al-Khaeriyah Qatar (Interview with AMP, October 20, 2016).

For the village community, pesantren are indeed considered as neighbors which must be supported by all their activities. This has to do with the nature of goodness and the greater reward compared to other jobs. The implication is that people often 
extend assistance when needed by the pesantren. (Interview with OA, 19 October 2016).

The alumni, who are active in various regions with various types of work and their abilities are among those who have a big responsibility to advance the pesantren, the place where they study. At least once a year, namely after Eid, usually the alumni visit the pesantren. Here they usually donate anything either financial or other donations. (KHA interview, 21 October 2016).

However, the most important role in the progress of pesantren is the parents of the santri, namely those outside the pesantren itself. In summary, the following is a questionnaire distributed to respondents. From the questions that may choose more than one, "Which party is made into a network of cooperation by pesantren?" It was found that the parents received the majority of respondents (197), followed by the parent organization of pesantren (64). The alumni occupy the third place (53), followed by the government (46), NGOs (31), communities (18), and abroad (2).

From the explanation above, it appears that the pesantren seems to be just waiting for programs from the government or assistance from outside parties, including from abroad. The pesantren does not seem to have a person in charge of proactively thinking about and implementing development programs, which arise from the pesantren itself. Thus, the development program is not sporadic in nature, but is systematically organized.

There is a need for people here, even if they can be a body, in a pesantren whose job is to focus on development. Thus because the progress must be thought out, 
planned, and carried out as well as possible. Progress requires neat management (Mustari, 2014). It is not only done by waiting. With good management development can be realized systematically and holistically. He can advance the overall development expected by pesantren and society in general.

\section{E. CONCLUSION}

The following are conclusions about the role of pesantren on community development:

1. Basically pesantren do not object to development programs launched by the Indonesian government.

2. There are a number of pesantren that do not partially follow the development program of the Indonesian government because the teachings adopted by the pesantren are not in accordance with government programs such as family planning.

3. Most Islamic boarding schools do not reject government education policies. There is a rebuttal from traditional Islamic boarding schools about the application of school or madrasah curricula in pesantren, but it does not refuse to justify students to study in "packages" (Pursuit of Packages A, B, and C), namely open learning to obtain official government diplomas .

4. Development of village communities is a program provided by national programs through local government programs. In addition to the regional government, the village community also received development programs launched by the pesantren. This is because pesantren are considered as agents of 
development that receive various programs both from the center and from the regions.

5. The main pesantren network is the parents of santri, in addition to other parties such as organizations, government, alumni, NGOs, the community, and foreign parties.

6. With the government, many Islamic boarding schools collaborate in the field of village development such as agriculture, animal husbandry, cooperatives, small businesses, and so on.

7. In addition to delegating assistance to the Regional Level Implementation Unit (UPTD), the central government often provides assistance directly to the pesantren because it can be considered a pilot project of development to the surrounding community.

\section{REFERENCES}

Ball, Stephen J. (2013). Foucault and education: Disciplines and knowledge. Routledge.

Hidayat A, Machali I. (2012). Pengelolaan Pendidikan: Konsep, Prinsip dan Aplikasi dalam Mengelola Sekolah dan Madrasah. Yogyakarta: Kaukaba.

Jamal E. (2017). "Membangun momentum baru pembangunan pedesaan di Indonesia." Jurnal Penelitian dan Pengembangan Pertanian. Sep 27;28(1):7-14. 
Korten, David C. and Alfonso, Felipe B. (eds.). (1981). Bureaucracy and the Poor: Closing the Gap. Singapore: McGraw-Hill International Book Company, Copyright by Asian Institute of Management, Makatai, Metro Manila, the Philippines.

Lauer, Robert H. (1982). Perspectives on social change. Allyn \& Bacon.

Lewis, Sarah. (2015). "Qualitative inquiry and research design: Choosing among five approaches." Health promotion practice16.4: 473-475.

Malik J. (2005). Pemberdayaan Pesantren. Yogyakarta: Pustaka Pesantren.

Marzali, Amri. (2016). Antropologi \& Pembangunan Indonesia. Prenada Media.

Maskun, Sumitro. (1993). Pembangunan masyarakat desa: asas, kebijaksanaan, dan manajemen. Media Widya Mandala.

Mckenzie, Janet (2014). Changing education: A sociology of education since 1944. Routledge.

McMichael, Philip. (2012). Development and social change: A global perspective. Pine Forge Press.

Mustari, Mohamad, and M. Taufik Rahman. (2010). Peranan pesantren dalam pembangunan pendidikan masyarakat desa. MultiPress.

Mustari, Mohamad. (2014). Manajemen Pendidikan. Raja Grafindo, Jakarta.

Parsons, Talcott. (2013). The social system. Routledge. 
Pohl, Florian. (2006). "Islamic Education and Civil Society: Reflections on the Pesantren Tradition in Contemporary Indonesia," Comparative Education Review 50, no. 3 (August): 389-409.

Poloma, Margaret M. (1979). Contemporary sociological theory. Weidenfeld \& Nicolson.

Rahardjo, M. Dawam. (1985). Pergulatan dunia pesantren: membangun dari bawah. Perhimpunan Pengembangan Pesantren dan Masyarakat.

Rahman, M. Taufiq. (2014). Penguatan kembali Umat Islam dalam menghadapi problematika Masyarakat Industri. Discussion Paper. Jurusan Sosiologi UIN SGD Bandung, Bandung. (Unpublished).

Riggs, Fred W. (2006). "The prismatic model: Conceptualizing transitional societies." Comparative Public Administration. Emerald Group Publishing Limited.

Riggs, Fred Warren. (1973). Prismatic society revisited. General Learning Press.

Schumacher, Ernst Friedrich. (2011). Small is beautiful: A study of economics as if people mattered. Random House, (1973).

Soedjatmoko. (2001). Kebudayaan Sosialis. Jakarta: Melibas.

Sørensen, Georg. (2016). Democracy, dictatorship and development: economic development in selected regimes of the Third World. Springer. 
Suradisastra, Kedi. (2011). "Revitalisasi Kelembagaan untuk Mempercepat Pembangunan Sektor Pertanian dalam Era Otonomi Daerah." Jurnal Pengembangan Inovasi Pertanian 4.2. 